\title{
Diachronic Typology of Philippine Vowel Systems"
}

\section{Introduction}

It has been fairly well established (Dempwolff 1934, 1937, 1939]) that Proto-Austronesian (PAN) had a four-vowel system, usually symbolized by *i, *e, *a, and *u. It is also fairly evident that the daughter language from which the Philippine languages developed also had a four-vowel system. This daughter language will be called Proto-Philippines ( $\mathrm{PPH})$ throughout this paper. The $\mathrm{PPH}$ vowel system will be symbolized as $* i, * i, * a$, and $* u$, since whatever the phonological shape of $\mathrm{PAN} * \mathrm{e}$ was, it is probable that in $\mathrm{PPH}$ this vowel had become a mid to high central vowel. The great majority of four-vowel systems that remain in present day Philippine languages show similar systems, having high front and back vowels with two central vowels, one low, the other mid to high.

This paper is an attempt to identify the factors which brought about the break-up of the $\mathrm{PPH}$ four-vowel system in many languages and produced one known eight-vowel system, three known seven-vowel systems, at least a dozen six-vowel systems, and maybe twenty five-vowel systems. There are at least five languages, moreover, that have reduced the $\mathrm{PPH}$ four-vowel system to three vowels.

\section{Synchronic Background}

As a background to the discussion of vowel systems to follow, it will be useful to outline here the present phonological systems. This section will only describe consonant systems. The vowel systems will be described in the following section.

\subsection{Stops}

All Philippine languages have a glottal stop, though with varying degrees of functional load and varying patterns of distribution. The majority of Philippine languages have a contrast between voiced and voiceless stops at three points of articulation: $p, t, k / b, d, g$. these languages include: Abak, Aklanon, Agta, Ba-

Originally published as: Diachronic typology of Philippine vowel systems. In Current Trends in Linguistics 11: Diachronic, areal, and typological linguistics, ed. by Thomas A. Sebeok, 485-506. The Hague and Paris: Mouton and Co. (1973) 
langao, Batak, Bikol, Bolinao, Bontok, Buhid, Cebuano, Cuyuno, Dumagat (Casiguran Negrito, Umiray Negrito), Gaddang, Hiligaynon, Ibanag, Ifugao (Amganad, Batad, Bayninan, Guhang), Igorot (Santa Fe), Ilokano, Ilongot, Isneg, Itneg, Kalinga, Kallahan (Kayapa, Keley-i), Kankanay, Kapampangan, Kinaray-a, Magindanao, Malaweg, Mamanwa, Manobo (Agusan, Ata, Binukid, Dibabaon, Ilianen, Sarangani, Tigwa, Western Bukidnon), Mansaka, Maranao, Pangasinan, Porohanan, Sambal (Botolan), Sangil, Sangir, Subanon (Siocon), Subanun (Sindangan), Tagalog, Tagbanwa (Aborlan, Kalamian), Ternate, Tingguian, Waray, Ylanon, Yogad.

Two languages, Ivatan and Itbayat, have voiced and voiceless stops at four points of articulation: $p, t, c, k / b, d, j, g$.

The following languages have three voiceless and four voiced stops: $p, t$, $k / b, d, j, g$. Atta, Isinai, Samal, Tausug, Manobo (Surigao), and Sama Bangingi.

Inibaloi has the following system: $p, t, c, k, k / b, b^{w}, d, j, g$.

In the following languages, the voiceless bilabial stop has changed to a fricative. In each language, the stop system otherwise corresponds to the $p, t, k / b$, $d, g$ system listed above. $p$ has become $\phi,{ }^{1}$ in Kalagan, Manobo (Cotabato), and Tiruray. $p$ has become $f$ in Bilaan (Koronadal and Sarangani), and Tagabili. $p$ is indicated as an infrequent allophone of $\phi$, in Kalagan. In Sarangani Manobo, Atta, and Umiray Dumagat, fricative $\phi$ is given as an allophone of $p$.

Implosive $6, d$, and $g$ occur in Samal as allophones respectively of $b, d$, and $g$. In Sindangan Subanun, 6 and $d$ occur, allophones respectively of $b$ and $d$. In Samal, the implosive occurs only as part of a (phonetic) word initial geminate cluster. In Sindangan Subanun, it occurs as a single consonant syllable onset following pause or another stop.

\subsection{Fricatives}

\subsubsection{Bilabial and labiodental fricatives}

Six languages show bilabial or labiodental fricatives replacing voiceless bilabial stops. These are Kalagan, Manobo (Cotabato), and Tiruray ( $\phi)$; Bilaan (Koronadal, Sarangani) and Tagabili $(f)$. None of these languages have voiced

Editors' note: The IPA symbols $[\phi]$ and $[\beta]$ are used here to replace [p] and [७], respectively, which were used in the original publication. Other IPA symbols are also used in this paper, where appropriate, to replace now non-standard representations of phonetic values. 
fricatives at this point of articulation. A voiceless-voiced contrast at the labial position $(f / v)$ occurs only in Ibanag, and in Agta.

The following languages show a voiceless, bilabial or labiodental fricative: Gaddang $(\phi)$, Agta $(\phi)$, Buhid $(f)$, and Yogad ( $f$ alternating with $\phi)$.

The following languages show a voiced (but no voiceless) labiodental fricative ( $v$ ): Isinai, Itbayat, Ivatan, and Manobo (Western Bukidnon).

The following languages show a voiced (but no voiceless) bilabial fricative $(\beta)$ : Manobo (Ilianen), Sangil, Sangir, and Tagbanwa (Kalamian).

A number of languages have a voiced fricative allophone of their bilabial stop usually intervocalically: Tausug, Atta, Samal, and in Tigwa Manobo syllable-initial following $l$. In Kalamian Tagbanwa, $b$ and $\beta$ contrast but rarely. The usual situation is $b>\beta$ intervocalically, and medially following $l$ and $y$.

In Gaddang, final b becomes $\phi$ when suffixed with a vowel initial morpheme.

\subsubsection{Velar flat fricatives}

There are no languages in the sample which show a phonemic voiceless velar fricative, however, several languages (Atta, Buhid, etc.) have a voiceless velar fricative $(x)$ as an allophone of $k$ intervocalically. There are a number of languages which have a phonemic voiced velar fricative $\gamma$ : Aklan, Ilongot, Itbayat, Kankanay (as spoken in Sagada), Manobo (Western Bukidnon), Sangir, and Tagbanwa (Kalamian).

Although fully phonemic in Sagada, $\gamma$ in other Northern Kankanay barrios (e.g., Balugan) occurs only as an allophone of glottal stop.

A voiced velar fricative occurs as an allophone of the voiced stop intervocalically in Tausug, Atta, Buhid, Siocon Subanon, and Samal. In Tigwa Manobo, the fricative also occurs following $l$. In Kalamian Tagbanwa, $g$ and $\gamma$ contrast but alternate. The fricative usually occurs intervocalically and word-medial following $l$ and $w$.

Only four languages show the beginning of a voiced fricative series to correspond to the voiced stop series. These are Itbayat and Manobo (Western Bukidnon): $v, \gamma$; and Sangir and Tagbanwa (Kalamian): $\beta, \gamma$. 


\subsubsection{Alveolar grooved fricative}

All languages in the sample show $s$, except the Ifugao dialects (Amganad, Batad, Bayninan) and geographically adjacent Kallahan (Keley-i). In these languages, $s$ has become $h$. In Guhang Ifugao, $s$ is an allophone of $h$ following $i$ and $e$ in some environments.

The voiced alveolar grooved fricative $z$ occurs only in Agta, Ibanag, Mamanwa, and Manobo (Western Bukidnon). In Mamanwa, z has alveopalatal (3) and affricated (\$) variants.

\subsubsection{Glottal fricative}

$h$ occurs in the majority of the languages in the sample. It does not occur in Atta, Batak, Bontok, Gaddang, Ilongot, Inibaloi, Isneg, Itneg, Kalinga, Kankanay, Magindanao, and Mansaka. The dialect of Dibabaon spoken in the Agusan River valley, known as Mandaya, does not have $h$. Some of the latter languages, however, do show $h$ as an allophone of $s$, e.g., some dialects of Bontok (as that spoken in Mainit) freely substitute $h$ for $s$ in all environments. Likewise, Kalinga has an $h$ allophone for word-initial $s$ in some words. Isneg has $h$ as an allophone of $g, h$ occurring word-initial, between vowels within a word, and following word-medial juncture; $h$ and $g$ are free variants following $l$.

\subsubsection{Fricative allophones}

Phonetically dissimilar fricative allophones of voiced stop phonemes occur in a number of related languages in northern Luzon. In Bontok as spoken in Guinaang, $b, d$, and $g$ occur as syllable-finals. In syllable-initial position, the corresponding allophones are $f, \widetilde{t s}$, and $k_{+}^{h}$. A $b b$ geminate cluster is phonetically $v f$. Other dialects of Bontok have $v$, and $b$ as syllable initial variants of $b$ and $d$. In these dialects, there is no variant syllable-initial allophone of $g$. Distribution in some places is not describable in relation to the syllable but to the phonological word.

Balangao has similar allophones to Guinaang Bontok except that the syllable-initial allophone of $d$ is an alveopalatal (not alveolar) affricate.

In Ifugao, $\widetilde{p f}$ occurs syllable-initial and final, except preceding $\widetilde{p f}$ in an identical consonant cluster. In this position $b$ occurs; $b$ also fluctuates with $\widetilde{p f}$ syllable-final. $t$ and $d$ have the same distributional characteristics as $\widetilde{p f}$ and $b . k$ 
and $g$ are allophones. The sequence $k k$ occurs to form a geminate cluster. Slight voicing usually accompanies $k$ syllable-final.

In Kalinga, $b$ only occurs syllable-final. Its complementary allophones are $p^{y}$ occurring syllable-initial before $a$, and $\overparen{p \Phi}$ occurring syllable-initial before $i, o$, $u$. This affricate is occasionally voiced. The $d$ allophone occurs only syllablefinal, but $d \bar{z}$ and $\phi$ are also heard in this position. $\delta$ alternates with $t$ syllableinitial. $g$ occurs in all positions but fluctuates with $k$ in some positions. Similar fricative allophones also occur in areas geographically adjacent to Kalinga where the Banaw subdialect of Tingguian is spoken, as in Daguioman, eastern Abra.

\subsection{Laterals and vibrants}

All languages have at least one lateral, $l$. Two languages, Sangil and Sangir have two laterals, one of them retroflexed ( $l$ and $l$ ). Samal has a retroflexed $l$ in $\mathrm{C}_{2}$ of $\mathrm{C}_{1} \mathrm{VC}_{2}$ before silence or a consonant other than $l$.

The following languages have $r$ : Abak, Aklan, Atta, Batak, Bikol, Bolinao, Buhid, Cebuano, Cuyuno, Dumagat (Casiguran, Umiray), Gaddang, Hiligaynon, Ibanag, Igorot (Santa Fe), Ilokano, Inibaloi, Isinai, Isneg, Itbayat, Itneg, Ivatan, Kapampangan, Kinaray-a, Malaweg, Mamanwa, Manobo (Agusan, Dibabaon, Ilianen, Surigao, Western Bukidnon), Mansaka, Maranao, Pangasinan, Porohanan, Sama Bangingi, Samal, Sambal (Botolan), Sangil, Sangir, Tagalog, Tagbanwa (Aborlan, Kalamian), Tausug, Ternate, Tingguian, Tiruray, Waray, Ylanon, Yogad.

Some languages which do not have $r$ as part of the phonemic inventory indicate its occurrence as an intervocalic variant of $d$, e.g., Bilaan, Binukid, Magindanao, Tigwa Manobo, Kalagan, Gaddang, Sindangan Subanun. Many of the languages which show $r$ as a phoneme indicate morphophonemic fluctuation between $d$ and $r$ intervocalically. In many languages, adoption of Spanish loans seems to have been the major cause for the developing of the $d / r$ contrast. The phonetic quality of $r$ is either flapped or trilled in all of the languages stated above.

Some languages of northern Luzon, e.g., Bontok (except as spoken in Bontoc town), Balangao, Kalinga, and some dialects of Ifugao and of Tingguian have an $r$ allophone of $l$. The $r$ in these languages is never flapped or trilled. It 
varies phonetically from a central retroflexed vocoid in Bontok, Balangao, and Ifugao to a central resonant oral 'produced by relaxing the tongue and placing the tip either behind the lower front teeth or lower lip' in Kalinga and adjacent dialects of Tingguian. The distributional statements for $l$ and $r$ in these languages are relatively complex and of interest. In general, $l$ occurs as wordinitial, in geminate clusters, adjacent to a front vowel, following a consonant at the dental or alveolar points of articulation, or following any other consonant preceded by a front vowel. $l$ and flapped $r$ are full phoneme variants in Mamanwa ('word initially and medially') and Mansaka ('word-final, and between vowels').

\subsection{Nasals}

Only two systems occur, one having three points of articulation $(m, n, \eta)$, the other having a fourth point $\tilde{n}$. The languages with the $m n \tilde{n} \eta$ system are: Itbayat, Ivatan, Samal, and Tausug. All other languages have the $m n \eta$ system. Itbayat and Ivatan also have voiceless and voiced stops at the same four points of articulation. Samal and Tausug have four points of articulation in their voiced stop system, but only three voiceless stops. Several languages have stops at the alveopalatal position, but no corresponding nasal. They are: Atta, Inibaloi, Isinai, Manobo (Surigao), and Sama Bangingi.

\section{Diachronic Typology}

The following sections will discuss the dynamic processes which brought about the present Philippine vowel systems, beginning with the three vowel systems and concluding with the eight vowels of Casiguran Dumagat. ${ }^{2}$

\subsection{Three-vowel systems}

The statements that are made here must be considered to be tentative. The data from which the conditioning factors here described have been deduced is in most cases minimal. The primary data has been a wordlist of slightly less than 400 items, containing 170 of the Swadesh 200 list, plus various other terms having high cognate productivity. These are the lists contained in Reid (1971). Where other linguists have made diachronic statements in their published works (as in Lindquist, Forsberg, and Healey [1959], and Abrams [1963]), these have been taken into consideration and checked against the data available to me. 
Most of the existing three-vowel systems in the Philippines are located in the Visayan Islands. These include: Abak, Aklanon, Cebuano, Porohanan (at present according to Wolff 1967 a subdialect of Cebuano), ${ }^{3}$ and Waray. One three-vowel language geographically distant from the Visayan Island is Tausug.

Most of these systems have developed by the merging of the mid to high central vowel $\mathrm{PPH}$ *i (labeled 'pepet' from here on) with the high back vowel. Merging also occurred in a number of other languages that have since expanded their inventory to five or more vowels. The various ways that pepet developed in Philippine languages has been discussed in Conant (1912). Of the present three-vowel systems, Conant discusses only Cebuano and Tausug (named by him respectively, Bisayan and Sulu). Additional information for Aklanon (Zorc 1969) indicates that this language also participated in the $\mathrm{PPH} * \mathrm{i}$ $>u$ shift. This is expected since there is both quantitative and qualitative evidence to indicate that these languages (apart from Tausug) were until recently undifferentiated. In other words, Cebuano, Aklanon, and probably also Abak have retained the three-vowel system which was already present or developed in their immediate proto-language by merging of $\mathrm{PPH} * \mathrm{i}$ and $\mathrm{PPH}{ }^{*} \mathrm{u} .{ }^{4}$

Waray (or Samar-Leyte) normally classified as a three-vowel system has according to Wolff (1968) two phonological systems. One set of speakers use a four-vowel system having a pepet vowel, whereas other speakers use a threevowel system, where $u$ generally corresponds to the pepet appearing in forms in the four-vowel system. Wolff believes that the three-vowel system has not developed as a result of the merger of $* i$ and $* u$ but by replacement, as a result of borrowing from Cebuano. Since Porohanan (or Camotes Island dialect) is probably genetically more closely related to Waray than to Cebuano (Wolff 1967), it is probable that the three-vowel system of Porohanan is likewise a re-

3 Published materials in these languages frequently utilize five vowel symbols, but phonological statements usually indicate that $e$ and $o$ represent allophonic variants for these languages. Some analysts, however, contend that Waray and Cebuano presently have a five-vowel system. On the other hand, analysts state that some dialects of Bikol still have a three-vowel system. I have chosen to follow Constantino's analysis of Naga Bikol as having a five-vowel system.

4 Conant (1912) indicates that $*_{i}>i$ in Cebuano forms having a following $i$, and also possibly in Tausug. 
sult of *i replacement, rather than merger. Wolff notes that Porohanan vocabulary is overwhelmingly Cebuano in origin.

\subsection{Four-vowel systems}

As indicated above, the majority of the more than thirty four-vowel systems consist of one high front vowel, two central vowels-one low, the other mid to high-and one back vowel. The front and back vowels in most of these languages have considerable phonetic variation, sometimes free variation, but in most instances conditioned by various environments. It is of interest to note that in phonemic descriptions of a number of languages (Bontok, Cuyuno, Inibaloi, Itneg (Binongan), Ivatan, Kankanay (Northern), Mamanwa, Maranao, and Sambal (Botolan)) the back vowel has been represented by $o$ rather than $u$, reflecting the fact that although $[\mathrm{u}]$ does occur in some environments the lower variant o] is more frequent and is considered to be the phonemic norm.

In addition to these languages, the following languages also have four vowels in which pepet is reflected as a central vowel: Batak, Bolinao, Ilongot, Itbayat, Kallahan (Kayapa Proper), Kinaray-a, Magindanao, Manobo (Binukid, Dibabaon, Ilianen, Tigwa, Western Bukidnon), Mansaka, Pangasinan, Tagbanwa (Kalamian, Aborlan), Tingguian, and Ylanon.

In some four-vowel systems, $\mathrm{PPH}^{*} \mathrm{i}$ is no longer reflected as a central vowel. $\mathrm{PPH}^{*} \dot{\mathrm{i}}>\boldsymbol{o}$ in Kalinga and Manobo (Ata), forming a two way contrast in back vowels, whereas in some dialects of Ilokano, as well as in Kallahan (Keleyi) $\mathrm{PPH}^{*} \mathrm{i}>e$ forming a two way contrast in front vowels.

An unpublished paper by Elkins (1966) provides further interesting information regarding the development of the four-vowel systems in five of the Manobo languages-Bukidnon, Dibabaon, Ilianen, Tigwa, and Western Bukidnon. Each of these languages has two central vowels, $a$ and $i$, the latter vowel ranging in quality from a low, central, close unrounded vowel in Tigwa and Dibabaon, to a mid central open unrounded vowel in Ilianen and Western Bukidnon, to a mid central close unrounded vowel in Bukidnon. In each of these languages, except Bukidnon, there is partial loss of contrast, between the two central vowels. Elkins (1963) describes this phenomenon synchronically as it occurs in Western Bukidnon Manobo. In his unpublished comparative paper, however, he describes the problem from a diachronic point of view. On the ba- 
sis of the predictability of the neutralization of contrast Elkins establishes two morphophonemes /A/ and /E/. (Elkins has used the symbol $e$ to represent pepet.) Thus, he says, " $A$ is phonemically /e/ but historically *a, and $E$ is phonemically /a/ but historically *e."

Elkins further describes the neutralization of contrast as follows. Loss of contrast occurs in a consonant-vowel-semivowel syllable (CVS) since of the two vowels only pepet may occur in this position. However, when suffixation rearranges a CVS syllable in which pepet occurs so that the syllable pattern changes to $\mathrm{CV}$, the pepet is replaced by $a$. Elkins gives the following examples $(e=i)$ : Ilianen, Tigwa, Western Bukidnon saßew, Dibabaon sabew 'broth, soup', but when suffixed with -an, the forms become respectively saßawan and sabawan. Likewise, in each of these four languages the form baley 'house' occurs, but with -an suffixation, it appears as balayan. He rewrites the bases as $s a b A w$, and balAy, and reconstructs for Proto-Manobo (PM) the forms PM *sabaw and *balay. In Ilianen and Western Bukidnon, the sequence /a?e/ never occurs. When a root ending in /a?/ is suffixed by the -en affix, the $e$ of the affix is replaced by /a/ as in the following: midraha? + - en > mid?aha?an 'to see, look at something'. By analogy (and by comparison with the Bukidnon cognate), a form like ka?an 'eat' occurring in Ilianen and Western Bukidnon is rewritten as ka?En (Bukidnon ka?en 'eat') and is reconstructed for Proto-Manobo as PM *ka?en.

Loss of contrast between $a$ and pepet likewise occurs in prepenultimate syllables in Ilianen and Western Bukidnon Manobo. Thus, when a penultimate syllable containing an $a$ vowel becomes prepenultimate because the base is suffixed, $a$ is replaced by pepet.

\subsection{Five-vowel systems}

The majority of the five-vowel systems consist of two front vowels (usually $i$ and $e$ ), one low central vowel (a), and two back vowels (usually $u$ and $o$ ). These will be discussed under 3.3.1. One language, Sarangani Manobo, has one high front and one high back vowel with three central vowels (discussed in 3.3.2), and one language, Manobo as spoken in Agusan and Surigao, has two front vowels ( $i$ and $\propto$ ), two central vowels ( $i$ and $a$ ), and one back vowel, $u$ (discussed in 3.3.3). 
3.3.1 The five-vowel systems having two front, two back, and one central vowel developed in two fairly distinct ways. The first group developed first a threevowel system by the merger of * $i$ with one or more of the other three vowels, and then expanded their phoneme inventory with the addition of $e$ and $o$. The other group rearranged the proto-four-vowel system, by the backing of the pepet vowel to $o$ giving two back vowels, and then developed an $e$ vowel to form two front vowels.

The first group of languages includes Atta, Bikol, Ibanag, Isneg, Itawis, Kapampangan, Malaweg, and Tagalog.

In Tagalog, $* \dot{i}>i$, except in some environments in which an assimilative process brought about a $u$ reflex (see Llamzon 1966). The other languages all show $* \dot{\mathbf{i}}>a$. (This reflex in Bikol occurs only in penultimate syllables. In ultimate syllables, $* \dot{\mathbf{i}}>u_{\text {.) }}$ The merger of $* \dot{i}$ and $*$ a probably developed independently in Bikol and Kapampangan. Bikol appears to be more closely related to Tagalog than to Kapampangan. Dyen (1953:6-7) in fact argues that Bikol and Tagalog (and Bisayan) were recently one language, or still are. It would seem then that the various mergers of $\mathrm{PPH}{ }^{*} \mathrm{i}$ in these three languages (with * $\mathrm{i}$ in Tagalog, * $\mathrm{u}$ in Bisayan, and *a and * $\mathrm{u}$ in Bikol) are of relatively recent origin. The other languages mentioned above in which $\mathrm{PPH}_{\mathrm{H}}{ }_{i}>a$ (Atta, Ibanag, Isneg, Itawis, and Malaweg) are all closely related and probably share in a change which occurred in their immediate proto-language. ${ }^{5}$

It has generally been assumed (note for example Llamzon 1969:14; Yap 1967:30) that the development of $e$ and $o$ in these languages has been as a result of borrowing from Spanish (and English). There are few publications, however, that attempt to support this with evidence. One which does is Whittle and Lusted (1963), which gives a clear statement of how Spanish loans have become assimilated into Atta. But in Atta, as well as in the other languages of this group, there is clear evidence that $e$ and $o$ have also developed as a result of internal processes. There is evidence that $\mathrm{PPH}$ laryngeals occurring medially between $a$ and a high front or back vowel were lost and the resulting vowel sequence became respectively $e$ or $o$. There seems to be no instances of the

Dyen (1965:31) shows Itawis and Malaweg forming part of the Isneg Hesian, which in turn with Ibanag forms part of the Banagic cluster. 
sequences ai or au in inherited Atta forms. Whittle and Lusted further point out that when suffixation would bring about a cluster of ai or au at the morpheme juncture, the vowel clusters become respectively $e$ and $o$ (plus length). They also state that the diphthongs ay and aw when occurring at the end of words become respectively $e$ and $o$ (with length) if followed by an attributive such as a possessive pronoun, e.g., balay 'house' becomes bale: mi 'our house', and lappaw 'flower' becomes lappo: na 'it's flower.'

Similar changes have taken place in Isneg. Note *taga?inip ${ }^{6}>$ IsG tagenap $^{*}$ 'dream'; "napa?it > IsG napet 'bitter', etc.

In Tagalog, the high front and back vowels had lowered allophonic variants in prejunctural syllables. In these environments, morphophonemic variation now occurs, e.g., Tagalog: babae /babá?eh/ /babá?ih/ 'female', sakit /sakít/ /sakét/ 'sickness', balut /balút/ /balót/ 'duck's egg', bukod /bukód/ /bukúd/ 'separate'.

Moreover, in spoken Tagalog, ay alternates with ey or $e$, as in mayroon /mayro?ón/ /meyró?n/ /méron/ 'there is, there are'; the same alternation occurs with forms having the sequence ai, as in kailan /ka?ilán/ /kaylán/ /keylán/ /kélan/ 'when' (data from Yap 1967:129-30). Although not mentioned in Mrs. Yap's thesis, aw sequences are also heard to alternate with o, as in ayáw ko ayó ko 'I don't want to', and kaunti? konti? 'a little'.

In Kapampangan also, -ay and - aw sequences have been reduced to $e$ and $o$, e.g., *bigsay > bagse 'canoe paddle'; *suklay > sukle 'comb'; *balay > bale 'house'; *?aldaw > aldo 'day, sun'.

Although it may have taken Spanish and English borrowings to produce minimal pairs and establish contrast to the satisfaction of the phonemicists, it would seem that the $e$ and $o$ vowels were to some degree already established in the languages, by internal processes, by the time Spanish borrowings were being accepted. In languages in which diphthong reduction has not occurred and

\footnotetext{
Asterisked forms are postulated reconstructions. In some cases the form may be $\mathrm{PPH}$ in origin; in other cases they are lexical innovations peculiar to a restricted group of languages within the Philippines. Until more systematic subgrouping of Philippine languages has been done, it would be premature to attach labels to these earlier stages of the languages. The forms used as a basis for the reconstruction of asterisked forms occur in the lists of Reid (1971).
} 
the $\mathrm{PPH}$ four-vowel system has been retained, Spanish and English loans with $e$ and $o$ vowels have been assimilated to the high front and back vowels. The implication is that the three-vowel systems that expanded to five-vowels already had begun to reduce diphthongs to mid front and back vowels when Spanish loans began to influence the language.

The second group of languages which have developed a five-vowel system include Ifugao as spoken in Amganad (IFGAG), Bayninan (IFGBY), and also the Subanon of Siocon (SUBSC). One of the Ifugao languages (IFGBT) has since expanded its inventory to six vowels (see 3.4.3). In each of these languages $\mathrm{PPH}$ *i >o in most environments, e.g., *?u:tik > IFGAG Putok; IFGBY Pu:to? 'brain'; *takdig > IFGAG, IFGBY ta?dog 'stand'; * ?atip > IFGAG, IFGBY Patop 'roof'.

The following examples illustrate the pepet reflex in SuBSc: *lilabun > (g)lolabuy 'afternoon'; *2itim > (g)itom 'black'; *?u:tik > (g)utok 'brain'.

In Amganad and Bayninan Ifugao, however, the sequence *-iw and *iy became respectively *-aw and *ay subsequently becoming $o$ and $e$; e.g., *ta:kiw $>$ *?a:kiw > *1a:kaw > IFGAG, IFGBY ?a:ko 'steal'; *?algiw > IFGAG, IFGBY Palgo 'day, sun'; *ki:diy > *ki:day > IFGAG ki:de, IFGBY Pi:de 'eyebrow'; *?altiy $>$ *?altay > IFGAG Palte, IFGBY Polte 'liver'.

In Bayninan Ifugao, a further development to $e$ also took place. In unaccented (that is, nonlengthened) penultimate syllables, and in closed final syllables, *i $>e$, if a contiguous consonant was $l$, $t$, or $\eta$; e.g., *pa?it $>$ paet 'bitter'; *tamil > tamel 'cheek'; *?u:lin > ?u:ley 'charcoal'; *lima > lema 'five'; *kilat > kelat 'lightning'.

Lowering of high vowels to mid in syllables preceding mid vowels has also occurred in Bayninan Ifugao; e.g., " Đi:tit > ye:tet 'black'; *wi:?it > we:et 'morning'; "subit > hobet 'thorn'.

In Siocon Subanon, the second change $* \dot{i}>o$ is probably a relatively recent development in that the neighboring Sindangan Subanun dialect has not participated in the change. Siocon Subanon has also developed $o$ and $e$ through the loss of laryngeals between $a$ and a high vowel, and subsequent reduction of the resulting diphthongs; e.g., *ta?un > ton 'year'; *nahik > monek 'climb'; *ta?ih $>$ gote 'excrement'; *la?in > len 'other'. 
3.3.2 The vowel system of Sarangani Manobo $(\mathrm{MBS})$ is apparently unique in the Philippines, consisting of one front, one back (written as $o$, not $u$ ), and three central vowels.

The mid central vowel $\Lambda$ reflects $\mathrm{PPH}^{*} \mathrm{i}$ in some forms and $\mathrm{PPH}_{\mathrm{H}}$ *a in others; e.g., *dakil > dakıl 'big'; *2u:tik > qotık 'brain'; *ginaw > gınaw 'cold'; *tagaqinip > tıg^qinıp 'dream'; *saladin > sıladıy 'deer'. The $\Lambda$ reflex of *a appears to be a result of the neutralization of contrast that has been described by Elkins for other Manobo languages, e.g., MBS baba + - $n$ > bıba?^n 'to carry on the back'. An examination of the approximately 150 forms in DuBois' (1969) Sarangani Manobo dictionary (containing around 5,000 entries) in which the high central vowel $\dot{i}$ occurs, gives the impression that these are not inherited forms, but probably borrowings from some other language. None of the forms are from the area of 'basic' vocabulary, and few have cognates in other Manobo languages. The source of the borrowings has not yet been identified, but it is possibly Kalagan or Bilaan. Those few forms which have cognates in other Manobo languages show $i$ as a reflex of * $\dot{i}$, e.g., MBS kitin 'to pull, as on a rope', Western Bukidnon Manobo (MBCw) kitim 'to straighten out an object'; MвS kipkip 'to clasp in the arms', $\mathrm{MвCW}$ kipkip 'to embrace'; MвS bitin, $\mathrm{MвCW}$ biting 'unripe coconut'; MвS bijkkg 'interrupt, put a stop to, scatter', $\mathrm{MBCw}$ bijkkag 'shatter, break up, of a gathering of people when they separate'; MвS bayig 'type of tree', $\mathrm{MвCW}$ bayig 'a tall bamboo'.

3.3.3 The vowel system of Manobo as spoken in Agusan and Surigao is also apparently unique in the Philippines, consisting of two front vowels, one high and one low, two central vowels and a high back vowel. Apart from the low front vowel $\propto$, the system reflects the PPH four-vowel system. Weaver (1963) provides over a dozen equations with other Manobo languages (Dibabaon, Binukid, and Western Bukidnon Manobo). From this material it would appear that $* 1>\emptyset$ between a sequence of $a$ vowels, and also when $* 1$ was the final consonant of a CVC syllable. In these environments the Mandayan dialect of Dibabaon has a long a vowel, interpreted as a geminate cluster aa, and Agusan Manobo has $\alpha$.

\subsection{Six-vowel systems}


The six vowel systems may be grouped into three types: (1) those that retained the $\mathrm{PPH}$ four-vowel system and added mid front and back vowels; (2) those in which $\mathrm{PPH}^{*} \mathrm{i}$ merged with one of the other three proto-vowels, in some environments; (3) those in which $\mathrm{PPH}_{\mathrm{H}}^{*} \mathrm{i}$ became backed to $o$, and which subsequently developed mid front and central vowels.

3.4.1 Languages retaining the $P P_{H}$ four-vowel system include Sindangan Subanun, Kalagan, Cotabato Manobo, and Gaddang.

Sindangan Subanun (SUBS) did not participate in the pepet shift to $o$ which occurred in Siocon Subanon. However, the loss of laryngeals between $a$ and a following high front or back vowel which occurred in Siocon has also occurred in Sindangan. Moreover, in Sindangan (but apparently NOT in Siocon), $k$ was also lost between $a$ and $i$. In Sindangan, they have become respectively ee and oo; e.g., *dahun > SUBS doon 'leaf'; *ta?un > toon 'year'; *nahik > neek 'climb'; *ta2ih > tee 'excrement'; *la?in > leen 'other, different'; *sakil > SuBS seel, SUBSC sakil 'heel'; *sakit > SUBS seet, SUBSC sakit 'pain'.

In Kalagan (KLG), laryngeals were lost between vowels in a stem and many resulting vowel sequences were reduced; e.g., *pu?ud > pud 'thigh'; *ta?as > tas 'up'; *mama?in > mamin 'betel nut'. Sequences of au and ai became respectively $o$ and $e$ only if the stem final consonant was a velar stop or nasal, or a glottal stop; e.g., *la?un > loy 'say'; *bahu? > bo? 'smell'; *lahin > ley 'unripe'; *da?ig > deg 'many'; *tahi? > te? 'sew'. In other environments the au and ai sequences were not reduced, e.g., "pa?it > pait 'bitter'; *ha?in > Pain 'where'; "bahu > bau 'turtle'.

The assimilative process is currently operating in Kalagan on the vowel sequence resulting from juxtaposition of an $a$ final prefix (e.g., $m a-, k a-$ ) with an $? u$ initial stem. ${ }^{7}$ Some forms are already fixed, others still have alternate pronunciation. Thus, KLG kobayan 'wife' (from Pubay + ka- -an) and KLG moli 'return' (from Puli $+m a-$ ), are always pronounced with an $o$ vowel, whereas KLG molug 'fall' has a variant pronunciation of mawlug.

This assimilative process has apparently not yet begun to operate on a?i sequences resulting from juxtaposition of $-a$ final prefixes with $2 i$ - initial stems,

Personal coommunication from Don Murray, SIL, November, 1969. 
although reduction of glottal stop in such a sequence is regular. Thus, $m a^{-}+$ Pitim 'black' is regularly maitim.

Other instances of KLG $o$ and $e$ are not accounted for by the above statements, and may be borrowings from Bilaan (BIL), e.g., KLG Rimo?, BIL Rimo? 'work'. There is ample evidence for *u > KLG $u$ before 2, e.g., KLG dugu? 'blood', lutu? 'cook', baru? 'forehead', pusu? 'heart', etc.

The reflex of $\mathrm{PPH}^{*} \mathrm{i}$ in Cotabato Manobo (MBKC) is $i$. The origin of the $o$ and $e$ vowels, however, is obscure. Elkins has made a complete search for Western Bukidnon Manobo cognates of all the forms having $e$ and $o$ vowels in Johnston's (1967 ms.) Cotabato Manobo dictionary (containing about 3,500 stems) and found that there were relatively few which he could positively relate to Western Bukidnon forms. ${ }^{8}$ Such forms include: $\mathrm{MBKC}$ ?umow, $\mathrm{MBCW}$ Pumiw 'call'; МвКC siyow, МвCw siyiw 'nine'; МвКC godoy, МвCw guyud 'to pull'. The majority of the forms containing $o$ and $e$ vowels appear to be cognate with forms that only appear in Bilaan (BIL) or Tagabili (TGB). The Bilaan forms show either an $o$ vowel or a pepet where Cotabato Manobo has $o$. In those instances where an apparent cognate appears in Tagabili, the Tagabili form has an $o$ or 0

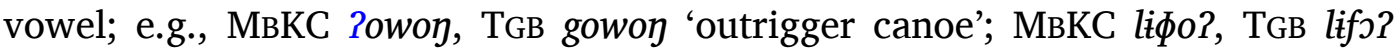
'ripe coconut'; МвКС Puton, Тяв ?uton Rel 'fish'; МвкC bulok, Тяв bulok, BiL bulik 'flower'; МвKC nido?o, BIL dìit 'many'; MвKC tulon, TGB tulon, BIL tulin 'tell';

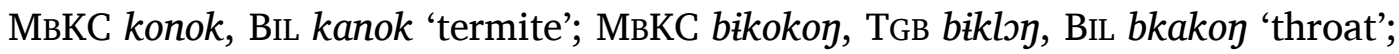
МвKC qonom, BIL qanim 'weave'; МвKC kilewey, BIL klubey 'eyebrow'; МвКС tukerey, BiL tukay 'small'.

It seems probable then, that forms containing $o$ in Cotabato Manobo were in most instances early borrowings from Bilaan or Tagabili, probably the latter. An alternate hypothesis, that Cotabato Manobo shared a period of common development with Bilaan or Tagabili, is not supported by other evidence.

It is possible that Cotabato Manobo has also borrowed from Tiruray; however, I do not have sufficient Tiruray lexical data to check this possibility.

Gaddang (GAD) expanded its four vowel inventory to six by loss of laryngeals between $a$ and a high vowel, with subsequent reduction of the resulting diphthongs to $o$ and $e$; e.g., *(mu)nahik > GAD munek 'climb'; *baybay > bebay

8 Personal communication from Richard Elkins, SIL, March, 1970. 
'sea'; *da2it > det 'sew'. In her published statement of Gaddang phonology, Madeline Troyer (1959) stated that $u$ and $o$ were free variants. She, however, indicated that a few minimal contrasts between $u$ and $o$ existed. She has subsequently indicated that she feels it is necessary to consider $u$ and $o$ as phonemically separate. ${ }^{9}$

There are also several examples where $e$ appears, where it was apparently a former allophone of $i$; e.g., gaфenin 'evening', ?aweg 'brook'.

3.4.2 The languages in which $P P_{H}{ }^{*} i$ partially merged with one of the other three proto-vowels include Sangir, Sangil, and Agta.

In Sangir (SAN) and Sangil (SNL) pepet became $i$ in final syllables in some environments. Elsewhere it retained its high central quality; e.g., "bili > SAN bìli, SNL bìli. 'buy'; *biRat > SAN Biha?, SNL Bira? 'heavy'; "tipiR > SAN tipihi?, SNL tipi:ri? 'mat'; "taginik > SAN, SNL tini? 'mosquito'. In some unstressed penultimate stem syllables there is evidence that *a has also become $\dot{i}$; e.g., *Rabi?i > SNL gibi 'night'; "sasa > SAN, SNL sisa 'nipa'; *mani > SNL mini? 'peanut'.

The development of $o$ and $e$ in these languages occurred in some forms by reduction of stem final aw and ay; e.g., *lanaw > SAN lano, SNL la:yo 'fly'; *Danaw > SAN dano, SNL la:no 'lake'; *balay > SAN bale, SNL $\beta a: l e$; *natay > SAN nate, SNL na:te 'dead'; *Ratay > SAN ate, SNL ?a:te 'liver'. In other forms these vowels have developed from $i$ and $u$, but the environmental factors are now obscure; e.g., "pi:li > SAN pile, SNL pi:le 'choose'; *ka:pis > *ka:pis > SNL

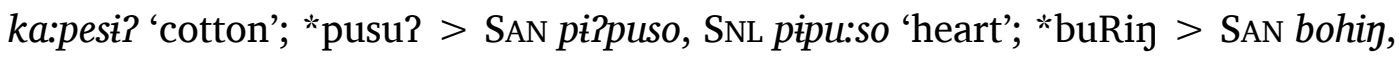
SNL $\beta$ o:rin 'charcoal'.

Agta has participated in the phonological shift of *i to $a$ which was described in section 3.3.1 as having taken place in the immediate proto-language of Isneg, Ibanag, Atta, Itawis, and Malaweg. In Agta, however, a subsequently split into $a$ and $\Lambda$. One analysis (Oates 1958) considered $a$ and $\Lambda$ to be allophones, $a$ occurring in unstressed syllables, $a$ elsewhere. In an unpublished subsequent analysis, Mayfield (1964) disagrees with the Oates analysis, presenting evidence to support phonemic contrast. The Oates statement, however, no doubt reflects the environmental factors which contributed to the phoneme

$9 \quad$ Personal communication from Madeline Troyer, April, 1967. 


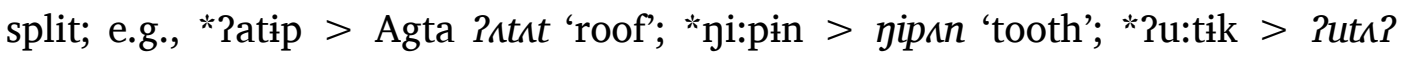
'brain'; *dijiR > dıyıg 'hear'.

3.4.3 The six-vowel languages in which $\mathrm{PPH}^{*_{i}}>\mathrm{o}$ include Batad Ifugao and Samal.

The shift of * $i$ to $o$ which characterizes other Ifugao dialects is also evident in Batad Ifugao (IFGBT), e.g., *tibal > IFGBT tobal 'answer'; *binig > bonog 'back'; *?u:lis > Pu:loh 'blanket'. In Batad also the sequences *-iw, and *-iy became respectively -aw and -oy. These diphthongs, however, did not become $o$ and $e$ as in Bayninan and Amganad, e.g., "natiy > IFGBT natoy 'dead'; *?uwiy $>$ Puwoy 'rattan'; *ki:diy > Ri:doy 'eyebrow'; *Palgiw > Palgaw 'sun'; * Pa:kiw $>$ ?a:kaw 'steal'. In Batad, $o$ and $e$ apparently developed from *u and *1 occurring adjacent to * $\mathrm{y}$, *k, and *l; e.g., *tunal > IFGBT togal 'bone'; *ta:kut > ta:Pot 'fear'; *tuktuk > to?to? 'forehead'; *?a:pul > ?a:pol 'lime'; *bu:lah > bo:lah 'red'; *?u:lin > ?u:len 'charcoal'; *tamil > tamel 'cheek'; *linit > lejot 'sweat'; *didin > dedey 'wall'.

A mid central vowel a also developed in Batad. It is in all places a reflex of *a, and appears to have developed in the following environments:

1. Open syllables initiated by a voiced stop or semivowel, when the vowel did not carry length; e.g., *mataba > matabə 'fat'; *la:ga > la:gə 'weave'; *luwa > lugwa 'tears'.

2. Lengthened open syllables initiated by a voiced stop, when the following consonant was *?, e.g., *ba:?in > ba:in 'embarrassment, shame'; *ba:?un > bə:un 'a debt one assumes as a responsibility';

3. Syllables initiated by a voice stop and closed by "y or a nasal, e.g., *baybay > bəybəy 'ocean'; *galaygay > galaygəy 'fingers'; *?aban > Pabən 'carrying blanket'; "gambilan > gambilan 'large bolo'.

4. $\partial$ in other environments seems to have developed in most instances as a result of vowel harmony, a process which occurs not infrequently in Batad Ifugao; e.g., “bala > bala 'lungs'; *2abba > 2abbə 'carry on the back'; note the following examples of vowel harmony involving other vowel sequences: *?abil $>$ Pobol 'weave'; *dakil > do?ol 'many'; *ma?id > mi?id 'there is none'.

Samal (SML) underwent a shift of * $i$ to $o$. This occurred mainly in ultimate syllables, although some proto-forms having pepet in both syllables have $o$ in 
both syllables in the Samal reflex. In other penultimate syllables $* i$ is reflected by $\dot{i}$ with gemination of the following consonant if the penultimate was open, e.g., *tanim > SML tanom 'plant'; *Tatip > atop 'roof'; *2itim > ettom 'black'; *kibil > kobol 'invulnerable'; *bitin > bittoy 'belly'; *bilih > billi 'buy'; *himpat > impat 'four'; *pidi? > piddi? 'sick'. *a in a penultimate syllable also became $i$ under some conditions, e.g., *Pallaw > illaw 'day'; *lambuk > limmuk 'fat'; *?ama? > imma? 'father'; *lalaki > lilla 'male; *kalat > killat 'rope'.

In Samal, $i$ and $u$ also split to $e$ and $o$ respectively. The environmental factors which brought about these splits have been obscured because of analogical leveling, vowel harmony, loanwords, and in the case of $o$, the fact that this vowel also developed from *i. However, it appears that $e$ and $o$ developed at least in the following environments:

1. Penultimate syllables initiated by a voiceless stop, e.g., *tikudtikud > tekodtekod 'heel'; *puti? > pote? 'white'; *tulay > to?olay 'bone'; *kuhap > kohap 'afternoon'.

2. Ultimate syllables closed by an alveolar consonant or *2, ${ }^{10}$ e.g., SML jeyen 'type of boat', kobet 'enlarge by tearing', babbel 'cut hair to a fringe', dallet 'flame up', pades 'graze the skin', peged 'smear on', benten 'carry in hand', sollet 'loin cloth'; astol 'anger', tompol 'dull'; toho? 'dry', boggo? 'canoe', edo? 'dog'.

3. Penultimate syllables preceding $e$ or $o$, e.g., bono? 'kill', boto? 'penis', bohe? 'water', se?ob 'burn', empon 'teeth', engkot 'tether', lede? 'boil'.

In Samal, moverover, *aw $>o$, *ay $>e$, and *uy $>i$; e.g., *tawah $>$ SML tittoa 'laugh'; *kawan > koan 'right'; *sawah > soa 'snake'; *dayu? > deo?

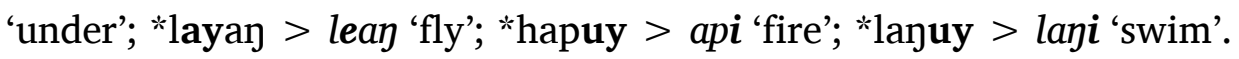

\subsection{Seven-vowel systems}

Three seven-vowel systems are known to exist in the Philippines. Tagabili and Balangao both show pepet reflexes for $\mathrm{PPH} * \mathrm{i}$. Bilaan, on the other hand, has undergone a merger of * $i$ and *a.

10 Samal data has been provided by Kemp Pallesen of the Summer Institute of Linguistics. Because of the lack of data from closely related languages, no attempt is made here to provide reconstructed forms. 
The Tagabili vowel system, as reported by Lindquist, Forsberg, and Healey (1959), consists of two front vowels, $i$ and $e[\varepsilon]$, two central vowels, $a$ and $\Lambda$, and three back vowels, $u, o$, and $\lrcorner$. The development of this system is discussed by Lindquist et al. in their paper. They state that from a study of some 150 probable cognates it was found that the proto-four-vowel system was reflected in the majority of cases by Tagabili $i, \Lambda, a$, and $u$. *a in a penultimate syllable became $\Lambda$ if the final syllable also contained * $\dot{*}$. $e$ developed from * $\dot{i}$ in two ways. Final $\mathrm{PPH}$ *iq became $e k$, with or without vowel harmony in the preceding syllable; in addition, a sequence of *Vi contracted to $e$. Mid back vowel $o$ has apparently developed from *a in a final syllable when it was followed by a nasal and preceded by ${ }^{*} \mathrm{u}$ in the penultimate. The low back vowel developed $\supset$ by splits in both *a and *u. *a became $\rho$ in a penultimate syllable if the final syllable contained * $\mathrm{u}$. Forms having * $\mathrm{u}$ in both ultimate and penultimate syllables show $\boldsymbol{\partial}$ reflexes if the final consonant was * $\mathrm{q}$ or * $\mathrm{k}$.

The development of the Bilaan vowel system has been discussed by Abrams (1963). The system is similar to the Tagabili system in that it has two front, two central, and three back vowels. In summary, Abrams states that *i became $e$ adjacent to * $\mathrm{q}$ and before word base final ${ }^{*} \mathrm{R}$. In these environments also, * $\mathrm{u}$ became $o$, as well as in the following environments: before word base final *k, after *h, and in the penultimate syllable when the base medial consonant was *h, *q, or *s. *a became $\rho$ in final open syllables, adjacent to *q or *k in closed syllables; and in the sequences $\mathrm{CaC}-\mathrm{C}$, *a became $\Lambda$ in final closed syllables except adjacent to ${ }^{*} \mathrm{q}$, ${ }^{*} \mathrm{k}$, or ${ }^{*} \mathrm{R}$, and in a penultimate syllable if in the ultimate syllable $* \mathrm{i}>e$. In other environments *a $>$ a. * $\dot{i}$ became $a$ in most environments, subsequently becoming $\supset$ in final syllables under the conditions stated above for *a.

The Balangao seven-vowel system differs from the Bilaan and Tagabili systems in having two front vowels, three central vowels, and two back vowels. Like Tagabili, Balangao generally reflects * $\dot{i}$ as $\dot{i}$, however, this vowel, as also the other three vowels, have split to form the present system. The conditioning factors which brought about these vowel splits are complex, and only the general outline will be presented here. The high vowels *i and * $u$ are generally reflected as $i$ and $u$ when the preceding consonant was a voiced stop. They are generally reflected as $e$ and $o$ when the preceding consonant was a voiceless 
stop. *a became $\Lambda$ in an ultimate syllable initiated by a voiced stop or semivowel; or by *m, *n, *1, or *s if the preceding vowel was high. *a became $u$ between a sequence of two voiced bilabial stops. *i became $\Lambda$ in open penultimate syllables initiated by a voiceless stop, *s, *h, or *1, also in ultimate syllables initiated by voiceless stops. In some environments *i also became $a, i$, and $u$.

\subsection{Eight-vowel system}

The only eight-vowel system demonstrated in the Philippines is Casiguran Dumagat. Headland and Wolfenden (1967) give a description not only of the vowel system but of some of the processes which brought about the system. ${ }^{11}$

Casiguran Dumagat has three front vowels, $i, e$, and $\varepsilon$, two central vowels, $\dot{i}$ and $a$, and three back vowels, $u, o$, and $\jmath$. Headland and Wolfenden's statement on the development of the system is as follows:

We postulate that the present system of eight vowels developed from a protolanguage of four vowels (*i, * $\mathrm{i},{ }^{*} \mathrm{u}$, and *a) to six by splits in the two high vowels $* i$ and $* u$, and the low vowel *a. *e developed from both *i and *a through occurrences contiguous to certain consonants...The $o$ developed from * $\mathrm{u}$ of the proto-language by an as-yet-unknown route... From the six vowel system, the eight vowel system finally developed when *ay/*ai and *aw/*au diphthongs in certain stressed syllables developed into $\varepsilon$ and $ว$ respectively. The sound pattern of these forms became frozen; new patterns of diphthongs were then introduced via contact with Tagalog or Ilokano, contiguous languages at present.

\section{Summary}

Several processes have contributed to the development of the vowel systems presently occurring in Philippine languages. These may be identified first in relation to those that effected a change in the position of the proto-mid to high vowel *i.

A number of languages merged *i with one of the other three proto-vowels, in some or all environments.

$* \dot{i}>i$ in Sangil, Sangir, Tagalog.

$* \dot{i}>u$ in Abak, Aklanon, Cebuano, Tausug.

11 Unfortunately, the value of this article is diminished because of the elimination of diacritic marks by the printer. The original manuscript is in the files of the Summer Institute of Linguistics, Philippines. 
$*_{i}>a$ in Agta, Atta, Bilaan, Ibanag, Isneg, Itawis, Kapampangan, Malaweg.

$* \dot{i}>a$ and $u$ in Bikol.

In some languages, pepet was either fronted or backed to form either an $e$ vowel or an $o$ vowel.

$* \mathrm{i}>e$ in Ilokano, Kallahan (Keley-i).

$* \dot{i}>o$ in Ifugao, Kalinga, Manobo (Ata), Subanon (Siocon).

In some languages, pepet split to form two vowels.

$* \dot{i}>\dot{i}$ and $o$ in Samal.

$* \dot{i}>\dot{i}$ and $\Lambda$ in Balangao.

In both these languages and also in Agta, *a split to produce $a$ and $\Lambda$. In Casiguran Dumagat, *a split to $a$ and $e$.

The following languages show mid or high central reflexes of * $\mathrm{i}$ : Batak, Bolinao, Bontok, Cuyuno, Ilongot, Inibaloi, Itbayat, Itneg (Binongan), Ivatan, Kallahan (Kayapa Proper), Kankanay, Kinaray-a, Magindanao, Mamanwa, Manobo (Agusan, Binukid, Dibabaon, Ilianen, Sarangani, Surigao, Tigwa, Western Bukidnon), Mansaka, Maranao, Pangasinan, Sambal (Botolan), Tagbanwa (Kalamian, Aborlan), Tingguian, Ylanon.

A summary of the reflexes of $* \mathrm{i}$ in thirty-one Philippine languages is found in Conant (1912). His conclusions, though in general correct, are in many places questionable because of inaccurate recording and inadequate data.

The development of $e$ and $o$ in many languages has come about by loss of laryngeals between $a$ and a high front or back vowel with subsequent reduction of the resulting diphthongs. In some languages this change has been reinforced by introduction of loanwords containing $e$ and $o$ vowels. This development occurred in Atta, Gaddang, Isneg, Kalagan, Subanon (Siocon), Subanun (Sindangan), and Tagalog.

The reduction of diphthongs *aw and *ay in Casiguran Dumagat produced 0 and $\varepsilon$ respectively. In Agusan Manobo, reduction of *ala and *al sequences produced $a$. Reduction of stem final *-aw and *-ay produced $o$ and $e$ vowels in Ifugao (Amganad, Bayninan), Samal, Sangil, and Sangir.

In some languages, $e$ and $o$ have also developed as a result of the splitting of * $\mathrm{i}$ and * $\mathrm{u}$. These languages include Balangao, Bilaan, Dumagat (Casiguran), Gaddang, Ifugao (Batad, Bayninan), Samal, Sangil, Sangir, Tagabili, and Taga$\log$. 
The low back vowel $\lrcorner$ developed by the splitting of *a in Bilaan, and *a and *u in Tagabili. 


\section{Appendix: Languages, Localities, and Sources}

The following is a list of languages mentioned in this paper. Each language is followed in square brackets by the source from which information has been taken. [SIL] indicates a published source with reference in Wares (1968). [SIL unp.] indicates an unpublished paper in the files of SIL Philippines. Information on the phoneme inventory of a number of languages is taken from the summary statements in Constantino (1965). These are indicated by [C]. Summary statements of the phonological systems of forty-three 'minor' Philippine languages, with bibliographical references and wordlists may be found in Reid (1971). The following list also indicates the general locality of the language, or the specific place where the information for the language was gathered.

Abak [C]: Kapul Island, Samar.

Aklanon [Zorc 1969]: Kalibo, Aklan.

Agta [SIL]: Central Cagayan Negrito; Gattaran, Cagayan.

Atta [SIL]: Northwestern Cagayan Negrito; Pamplona, Cagayan.

Balangao [SIL]: Natonin, Mountain Province.

Batak [SIL]: Lipsu, Puerto Princesa, Palawan.

Bikol [C]: Naga City.

Bilaan [SIL]: Koronadal, Southern Cotabato, and Sarangani, Southeastern Cotabato.

Bolinao [C]: Bolinao, Pangasinan.

Bontok [SIL]: Guinaang, Bontoc, Mountain Province.

Buhid [Barham 1958]: Bongabon, Mindoro Oriental.

Cebuano [C]: Cebu City.

Cuyuno [SIL]: Puerto Princesa, Palawan.

Dumagat (Casiguran) [SIL]: Negrito; Northern Quezon.

Dumaget (Umiray) [SIL unp.]: Negrito; Central Quezon.

Gaddang [SIL]: Butigui, Eastern Mountain Province.

Hiligaynon [C]: Iloilo City.

Ibanag [C]: Ilagan, Isabela.

Ifugao (Amganad) [SIL unp.].

Ifugao (Batad) [Newell 1970].

Ifugao (Bayninan) [Conklin 1967].

Ifugao (Guhang) [SIL].

Igorot (Santa Fe) [C]: Samta Fe, Neuva Vizcaya.

Ilokano [C]: Vigan, Ilocos Sur.

Ilongot [Rosaldo 1968]: Kakidugen, Nueva Vizcaya.

Inibaloi [SIL unp.]: Kabayan, Benguet.

Isinai [C]: Bambang, Nueva Vizcaya.

Isneg [SIL]: Dibagat, Kabugao, Northern Kalinga-Apayao.

Itbayat [Yamada 1966]: Itbayat, Batanes Islands. 
Itneg [SIL unp.]: Binongan, Baay, Eastern Abra.

Ivatan [SIL]: Basco, Batanes.

Kalagan [SIL]: Mainit, Southeastern Cotabato.

Kalinga [SIL]: Guinaang, Lubuagan, Kalinga-Apayao.

Kallahan (Kayapa Proper) [Afable 1969]: Nueva Vizcaya.

Kallahan (Keley-i) [SIL unp.]: Southern Ifugao.

Kankanay (Northern) [SIL unp.]: Sagada, Western Mountain Province.

Kapampangan [C]: San Fernando, Pampanga.

Kinaray-a [Reid 1970]: Lambunao, Iloilo.

Magindanao [SIL]: Cotabato.

Malaweg [C]: Rizal, Cagayan.

Mamanwa [SIL]: Santiago, Cabadbaran, Agusan.

Manobo (Agusan) [SIL]: Sagunto, La Paz, Agusan.

Manobo (Ata) [SIL]: Mansalinao, Davao.

Manobo (Binukid) [SIL]: Northern and Central Bukidnon.

Manobo (Cotabato) [SIL unp.]: Western Cotabato.

Manobo (Dibabaon) [SIL]: Northern Davao del Norte.

Manobo (Ilianen) [SIL]: Northern Cotabato.

Manobo (Sarangani) [SIL]: Caburan, Southern Davao del Sur.

Manobo (Surigao) [C]: Bahi Barubu, Surigao del Sur.

Manobo (Tigwa) [SIL unp.]: Southeastern Bukidnon.

Manobo (Western Bukidnon) [SIL]: Pangantocan, Bukidnon.

Mansaka [SIL]: Eastern Davao del Norte.

Maranao [SIL]: Lanao.

Pangasinan [C]: Lingayen, Pangasinan.

Porohanon [Wolff 1967]: Poro, Camote Islands.

Sama Bangingi [C]: Sulu.

Samal [SIL unp.]: Siasi, Jolo, Sulu.

Sambal (Botolan) [SIL unp.]: Central Zambales.

Sangil [SIL unp.]: Coastal areas of Southern Cotabato and Davao del Sur; Sarangani Island.

Sangir [SIL]: Sarangani Island, Davao.

Subanon (Siocon) [SIL unp.]: Central Zamboanga del Norte.

Subanun (Sindangan) [Brichoux 1970]: Central Zamboanga del Norte.

Tagabili [SIL]: Southwestern Cotabato.

Tagalog [Yap 1967]: Manila.

Tagbanwa (Aborlan) [SIL]: Central Palawan.

Tagbanwa (Kalamian) [SIL unp.]: Northern Palawan, Coron Island.

Tausug [SIL]: Jolo, Sulu.

Ternate [C]: Ternate, Cavite.

Tiruray [SIL]: Central Cotabato.

Tingguian [C]: Peñarrubia, Abra.

Waray [C]: Tacloban City.

Ylanon [C]: Lanao del Sur.

Yogad [SIL]: Echague, Isabela. 


\section{References}

Abrams, Norman. 1963. Historical development of Bilaan vowels and some consonant reflexes in Bilaan and related dialects. Philippine Sociological Review 11: 147-54.

Afable, Patricia O. 1969. Personal correspondence.

Barham, Marie R. 1958. The phonemes of the Buhid (Mangyan) language of Eastern Mindoro, Philippines. Studies in Philippine linguistics, ed. by Alan Healey, 4-9. Oceania Linguistic Monograph 3. Sydney: University of Sydney.

Brichoux, Robert. 1970. Sindangan Subanun phonemics. Pacific Linguistics Occasional Paper No. 24.

Conant, Carlos Everett. 1912. The pepet law in Philippine languages. Anthropos 7: 920-47.

Conklin, Harold C. 1967. Ifugao ethnobotany 1905-1965: The 1911 BeyerMerrill report in perspective. Economic Botany 21: 243-72.

Constantino, Ernesto. 1965. The sentence patterns of twenty-six Philippine languages. Lingua 15:71-124.

Dempwolff, Otto. 1934, 1937, 1939. Vergleichende Lautlehre des austronesischen Wortschatzes. Berlin: Dietrich Reimer

DuBois, Carl. 1969. Sarangani Manobo-English dictionary. Unpublished manuscript in the files of the Summer Institute of Linguistics, Philippines.

Dyen, Isidore. 1953. The Proto-Malayo-Polynesian laryngeals. William Dwight Whitney Linguistic Series. Baltimore: Linguistic Society of America.

Dyen, Isidore. 1965. A lexicostatistical classification of the Austronesian languages. International Journal of American Linguistics, Memoir 19. International Journal of American Linguistics 31 (1).

Elkins, Richard E. 1963. Partial loss of contrast between $a$ and $e$ in Western Bukidnon Manobo. Lingua 12: 205-210.

Elkins, Richard E. 1966. A comparative study of five Manobo dialects. Unpublished paper in the files of the Summer Institute of Linguistics, Philippines. Headland, Thomas N., and Elmer P. Wolfenden. 1967. The vowels of Casiguran Dumagat. Studies in Philippine Anthropology (in honor of H. Otley Beyer), ed. by Mario D. Zamora, 592-596. Quezon City: Alemar-Phoenix. 
Johnston, E. Clay. 1968. Cotabato Manobo dictionary. Unpublished manuscript in the files of the Summer Institute of Linguistics, Philippines.

Lindquist, Alice, Vivien Forsberg, and Alan Healey. 1959. The phonemes of Tagabili. Philippine Journal of Science 88: 225-43.

Llamzon, Teodoro A. 1966. Tagalili reflexes of PMP *e. Anthropological Linguistics 8(3):13-23.

Llamzon, Teodoro A. 1969. A subgrouping of nine Philippine languages. Verhandelingen van het Koninklijk Instituut voor Taal-, Land-, en Volkenkunde 58. The Hague.

Mayfield, Roy. 1964. The phonemes of Central Cagayan Agta. Unpublished paper in the files of the Summer Institute of Linguistics, Philippines.

Newell, Leonard E. 1970. The phonology of Batad Ifugao. Philippine Journal of Linguistics 1:101-117.

Oates, William J., and Lynette F. Oates. 1958. The phonemes of Central Cagayan Negrito. Studies in Philippine linguistics by members of the Summer Institute of Linguistics (Pacific Branch), 34-46. Oceania Linguistic Monograph 3. Sydney: University of Sydney.

Reid, Lawrence A. 1970. Kinaray-a word list. Unpublished.

Reid, Lawrence A., ed. 1971. Philippine minor languages: Word lists and phonologies. Honolulu: University of Hawai'i Press.

Rosaldo, Michelle. 1968. Phonology: Kakiduge:n Bugkalut. Unpublished paper.

Troyer, Madeline. 1959. Gaddang phonology. Philippine Journal of Science 88: 95-102.

Wares, Alan C. 1968. Bibliography of the Summer Institute of Linguistics, 1935-1968. Santa Ana, California.

Weaver, Daniel, and Marilou Weaver. 1963. The phonology of Agusan Manobo (with special reference to $æ$ ). Papers on Philippine Languages No. 1, 1-6. Manila: Institute for Language Teaching, University of the Philippines and the Summer Institute of Linguistics.

Whittle, Claudia, and Ruth Lusted. 1963. Interaction of coexistence phonemic system in Atta. Papers on Philippine languages No. 1, 26-39. Manila: Institute for Language Teaching, University of the Philippines, and Summer Institute of Linguistics. 
Wolff, John U. 1967. History of the dialect of the Camote Islands, Philippines, and the spread of Cebuano Bisayan. Oceanic Linguistics 6: 63-79.

Wolff, John U. 1968. The historical development of the Samar-Leyte Bisayan vowel system. Samar-Leyte Studies 2:33-39.

Yamada, Yukihiro. 1966. Phonology of Itbayaten. Philippine Journal of Science 94: 373-393.

Yap, Fe Aldave. 1967. A synchronic analysis of Tagalog phonemes. MA thesis, University of British Columbia.

Zorc, David, et al. 1969. Aklanon-English dictionary. Kalibo, Aklan: Aklan Printing Center. 